\title{
HUBUNGAN PENERIMAAN DIRI DENGAN KUALITAS HIDUP PADA PASIEN LUPUS ERITEMATOSUS SISTEMIK (LES) DI KOMUNITAS ODAPUS PROVINSI LAMPUNG (KOL)TAHUN 2018
}

\author{
Firhat Esfandiari ${ }^{1}$, Hetti Rusmini ${ }^{2}$, Nandito Ridho Santoso ${ }^{2}$
}

${ }^{1}$ Departemen Penyakit Dalam Rumah Sakit Natar Medika

2Prodi Pendidikan Dokter Fakultas Kedokteran, Universitas Malahayati

\begin{abstract}
ABSTRAK
Prevalensi SLE di Indonesia, jumlah penderita penyakit Lupus secara tepat belum diketahui. Prevalensi Lupus Eritematosus Sistemik (LES) dimasyarakat berdasarkan survey yang dilakukan oleh Prof. Handono Kalim, dkk di Malang memperlihatkan angka sebesar 0,5 $\%$ terhadap total populasi. Diketahui hubungan penerimaan diri dengan kualitas hidup pada pasien lupus eritematosus sistemik (LES) di Komunitas Odapus Provinsi Lampung (KOL) Tahun 2018. Jenis penelitian kuantitatif, rancangan survei analitik dengan pendekatan cross sectional, Populasi seluruh pasien Lupus sebanyak 40 orang. Sampel sebanyak 40 orang dengan teknik total sampling. Pengambilan data menggunakan lembar kuesioner. Teknik analisis data menggunakan uji statistik Chi Square. Distribusi frekuensi penerimaan diri pada pasien lupus eritematosus sistemik (LES) sebagian besar dengan kategori kurang baik sebanyak 22 responden (55,0\%). Distribusi frekuensi kualitas hidup pada pasien lupus eritematosus sistemik (LES) sebagian besar dengan kategori tinggi sebanyak 25 responden $(62,5 \%)$,Ada hubungan antara penerimaan diri dengan kualitas hidup pada pasien lupus eritematosus sistemik (LES) ( $p$-value 0,005 < a 0,05). OR:11,556.
\end{abstract}

Kata Kunci : Penerimaan Diri, Kualitas Hidup Pasien LES

\section{Pendahuluan}

Data prevalensi SLE di setiap negara berbeda-beda. Suatu studi sistemik di Asia Pasifik memperlihatkan data insidensi sebesar 0,9-3,1 per 100.000 populasi/tahun. Prevalensi kasar sebesar 4,2-45,3 per 100.000 populasi. The Lupus Foundation of America memperkirakan sekitar 1,5 juta kasus terjadi di Amerika dan setidaknya terjadi lima juta kasus di dunia. Setiap tahun diperkirakan terjadi sekitar 16 ribu kasus baru Lupus, di Indonesia, jumlah penderita penyakit Lupus secara tepat belum diketahui. Prevalensi Lupus Eritematosus Sistemik (LES) dimasyarakat berdasarkan survey yang dilakukan oleh Prof. Handono Kalim, dkk di Malang memperlihatkan angka sebesar 0,5\%

terhadap total populasi (Kemenkes RI, 2017).

Manifestasi Penyakit LES sangat luas, meliputi keterlibatan kulit dan mukosa, sendi, darah, jantung, paru, ginjal, susunan saraf pusat dan sistem imun. Oleh karena itu manifestasi penyakit LES sangat beragam dengan perjalanan penyakit yang bervariasi dan memiliki risiko kematian yang tinggi, sehingga memerlukan pengobatan yang lama dan seumur hidup. Untuk itu diperlukan pengenalan dini serta penatalaksanaan yang tepat (Kemenkes RI, 2016).

Selain mengalami gangguan organ, penderita SLE mengalami gangguan psikologis. Berdasarkan penelitian Noelle, dkk (dalam Wallace dan Hanhn, 1997) 
pada 35 penderita SLE, ditemukan bahwa $54 \%$ subjek mengalami gangguan psikologis. Saphiro mengatakan bahwa NPSLE (neuropsychiatric lupus) pada pasien SLE berkisar 12\%-71\% dan gangguan psikologis yang paling umum dialami adalah depresi. Gangguan psikologis dan kesulitan neurobehavioral yang umum terjadi pada penderita SLE diklasifikasikan pada psikosis, gangguan emosi, sindrom organik otak, kemunduran kognitif, reaksi obat (umum bagi penggunaan obat corticosteroidsi), gangguan fungsi, terganggunya sistem siklus ritme biologis kerja tubuh (bioritmik) dan berbagai gangguan pada saraf otonom (Novianty, 2014).

Berdasarkan survei yang peneliti lakukan di komunitas odapus Provinsi Lampung (KOL) Tahun 2018 dengan melakukan wawancara terhadap 10 penderita lupus eritematosus sistemik diketahui $70 \%$ diantaranya mengalami gangguan seperti merasa putus asa, pasien mengatakan merasa rendah diri dan merasa penyakitnya tidak akan sembuh. Berdasarkan fenomena tersebut peneliti tertarik untuk melakukan penelitian tentang hubungan penerimaan diri dengan kualitas hidup pada pasien lupus eritematosus sistemik (LES) di
Komunitas Odapus Provinsi Lampung (KOL) Tahun 2018.

\section{Metode Penelitian}

Jenis penelitian yang digunakan dalam penelitian ini adalah kuantitatif. Rancangan penelitian yang digunakan analitik dengan pendekatan cross sectional, yaitu penelitian yang mempelajari hubungan antara faktor resiko (independen) dan faktor efek (dependen) dimana pengukuran variabel bebas dan variabel terikat sekaligus pada waktu yang sama (Riyanto, 2011). Penelitian ini untuk mengetahui hubungan (variabel independen) penerimaan diri (variabel dependen) kualitas hidup pada pasien lupus eritematosus sistemik (LES).

Populasi dalam penelitian ini seluruh pasien lupus eritematosus sistemik (LES) di Komunitas Odapus Provinsi Lampung (KOL) sampai dengan Januari Tahun 2018 sebanyak 40 orang. Sampel yang diambil dalam penelitian ini adalah seluruh pasien lupus eritematosus sistemik (LES) sebanyak 40 orang. Pengambilan sampel menggunakan teknik total Sampling, yaitu sampel diambil dari keseluruhan total populasi.

\section{Hasil Penelitian}

\section{Karakteristik Sampel}

Tabel 1 Karakteristik usia pada pasien lupus eritematosus sistemik (LES) di Komunitas Odapus Provinsi Lampung (KOL) Tahun 2018

\begin{tabular}{ccc}
\hline Usia & Frekuensi & Persentase \\
\hline 20-30 Tahun & 8 & $20 \%$ \\
31-40 Tahun & 15 & 37,5 \\
41-50 Tahun & 16 & 40,0 \\
51-60 Tahun & 1 & 2,5 \\
\hline Jumlah & $\mathbf{4 0}$ & $\mathbf{1 0 0 , 0 0}$ \\
\hline
\end{tabular}

Berdasarkan Tabel 1 maka dapat diketahui bahwa usia pada pasien lupus eritematosus sistemik (LES) di Komunitas Odapus Provinsi Lampung (KOL) Tahun Tabel. 2 Karakteristik Jenis Kelamin pada pasien lupus eritematosus sistemik (LES) di Komunitas Odapus Provinsi Lampung (KOL) Tahun 2018
2018, sebagian besar adalah usia 41-50 tahun sebanyak 16 responden (40\%). 


\begin{tabular}{ccc}
\hline Jenis Kelamin & Frekuensi & Persentase \\
\hline Laki -laki & - & 0,0 \\
Perempuan & 40 & 100,0 \\
\hline Jumlah & $\mathbf{4 0}$ & $\mathbf{1 0 0 , 0 0}$ \\
\hline
\end{tabular}

Berdasarkan Tabel 2 maka dapat diketahui bahwa jenis kelamin pada pasien lupus eritematosus sistemik (LES) di Komunitas Odapus Provinsi Lampung
(KOL) Tahun 2018, seluruhnya adalah perempuan sebanyak 40 responden $(100 \%)$.

Tabel 3 Karakteristik pendidikan pada pasien lupus eritematosus sistemik (LES) di Komunitas Odapus Provinsi Lampung (KOL) Tahun 2018

\begin{tabular}{lcc}
\hline Pendidikan & Frekuensi & Persentase \\
\hline SMA & 16 & 40,0 \\
Perguruan Tinggi & 24 & 60,0 \\
\hline \multicolumn{1}{c}{ Jumlah } & $\mathbf{4 0}$ & $\mathbf{1 0 0 , 0 0}$ \\
\hline
\end{tabular}

Berdasarkan Tabel 3 maka dapat diketahui bahwa sebagian besar pendidikan pada pasien lupus eritematosus sistemik (LES) di Komunitas Odapus Provinsi Lampung (KOL) Tahun
2018, adalah pendidikan perguruan tinggi sebanyak 24 responden (60\%) sedangkan dengan pendidikan SMA/SMK sebanyak 16 responden $(40 \%)$.

Tabel 4 Karakteristik lama sakit pada pasien lupus eritematosus sistemik (LES) di Komunitas Odapus Provinsi Lampung (KOL) Tahun 2018

\begin{tabular}{lcc}
\hline Lama Sakit & Frekuensi & Persentase \\
\hline $1-2$ Tahun & 12 & 30,0 \\
$\geq 2$ Tahun & 28 & 70,0 \\
\hline \multicolumn{1}{c}{ Jumlah } & $\mathbf{4 0}$ & $\mathbf{1 0 0 , 0 0}$ \\
\hline
\end{tabular}

Berdasarkan Tabel 4 maka dapat diketahui bahwa sebagian besar lama sakit pada pasien lupus eritematosus sistemik (LES) di Komunitas Odapus
Provinsi Lampung (KOL) Tahun 2018, $\geq 2$ tahun sebanyak 28 responden (70\%) sedangkan lam sakit 1-2 tahun sebanyak 12 responden $(30 \%)$.

Tabel. 5 Distribusi frekuensi penerimaan diri pada pasien lupus eritematosus sistemik (LES) di Komunitas Odapus Provinsi Lampung (KOL) Tahun 2018 


\begin{tabular}{rcc}
\hline Penerimaan diri & Frekuensi & Persentase \\
\hline Baik & 18 & 55,0 \\
Kurang Baik & 22 & 45,0 \\
\hline Jumlah & $\mathbf{4 0}$ & $\mathbf{1 0 0 , 0 0}$ \\
\hline
\end{tabular}

Berdasarkan tabel 5 maka dapat diketahui bahwa penerimaan diri pada pasien lupus eritematosus sistemik (LES) di Komunitas Odapus Provinsi Lampung (KOL) Tahun 2018 sebagian besar dengan kategori kurang baik sebanyak 22 responden $(55,0 \%)$, sedangkan dengan kategori baik sebanyak 18 responden $(45,0 \%)$.

Tabel 6 Distribusi frekuensi kualitas hidup pada pasien lupus eritematosus sistemik (LES) di Komunitas Odapus Provinsi Lampung (KOL) Tahun 2018

\begin{tabular}{lccc}
\hline & Kualitas hidup & Frekuensi & Persentase \\
\hline Tinggi & & 25 & 62,5 \\
Rendah & 15 & 37,5 \\
\hline \multicolumn{2}{c}{ Jumlah } & $\mathbf{4 0}$ & $\mathbf{1 0 0 , 0 0}$ \\
\hline
\end{tabular}

Berdasarkan tabel 6 maka dapat diketahui bahwa kualitas hidup pada pasien lupus eritematosus sistemik (LES) di Komunitas Odapus Provinsi Lampung (KOL) Tahun 2018 sebagian besar dengan kategori tinggi sebanyak 25 responden $(62,5 \%)$, sedangkan dengan kategori rendah sebanyak 15 responden $(37,5 \%)$.
Analisis hubungan penerimaan diri dengan kualitas hidup pada pasien lupus eritematosus sistemik (LES) menggunakan uji chi-square dengan derajat kepercayaan $95 \%$ dan alpha (a) $5 \%$. Dengan hasil uji sebagai berikut:

Tabel 7 Analisa hubungan penerimaan diri dengan kualitas hidup pada pasien lupus eritematosus sistemik (LES) di Komunitas Odapus (KOL) Provinsi Lampung Tahun 2018

\begin{tabular}{|c|c|c|c|c|c|c|c|c|}
\hline \multirow{3}{*}{$\begin{array}{c}\text { Penerimaan } \\
\text { diri }\end{array}$} & \multicolumn{4}{|c|}{ Kualitas hidup } & \multirow{2}{*}{\multicolumn{2}{|c|}{ Total }} & \multirow{3}{*}{ p-value } & \multirow{3}{*}{$\begin{array}{c}\text { OR } \\
(95 \% \mathrm{CI})\end{array}$} \\
\hline & \multicolumn{2}{|c|}{ Rendah } & \multicolumn{2}{|c|}{ Tinggi } & & & & \\
\hline & $\mathbf{n}$ & $\%$ & $\mathbf{n}$ & $\%$ & $\mathbf{N}$ & $\%$ & & \\
\hline Kurang Baik & 13 & 59,1 & 9 & 40,9 & 22 & 100 & \multirow{3}{*}{0,005} & \multirow{3}{*}{$\begin{array}{l}11.556 \\
(2,115- \\
63,127)\end{array}$} \\
\hline Baik & 2 & 11,1 & 16 & 88,9 & 18 & 100 & & \\
\hline Total & 15 & 37,5 & 25 & 62,5 & 40 & 100 & & \\
\hline
\end{tabular}

Berdasarkan tabel 7 Hasil uji statistik $p$ value $=0,005$ lebih kecil dari nilai alpha ( $\alpha=0,05)$, sehingga terdapat hubungan yang bermakna antara hubungan penerimaan diri dengan kualitas hidup pada pasien lupus eritematosus sistemik (LES) di Komunitas Odapus (KOL) Provinsi Lampung Tahun 2018.
Hasil analisis diperoleh nilai OR: 11,556. Artinya penerimaan diri yang kurang baik memiliki risiko sebesar 11,556 kali kualitas hidup yang rendah dibandingkan dengan penerimaan diri yang baik.

\section{Pembahasan}

1. Penerimaan diri 
Berdasarkan hasil dari pengolahan data maka dapat diketahui bahwa penerimaan diri pada pasien lupus eritematosus sistemik (LES) di Komunitas Odapus Provinsi Lampung (KOL) Tahun 2018 sebagian besar dengan kategori kurang baik sebanyak 22 responden $(55,0 \%)$, sedangkan dengan kategori tidak cemas sebanyak 18 responden $(45,0 \%)$.

Komponen konsep diri didefinisikan sebagai semua pikiran, keyakinan dan keprcayaan yang merupakan pengetahuan individu tentang dirinya dan mempengaruhi hubungan dengan orang lain. Konsep diri tidak terbentuk waktu lahir, tetapi dipelajari sebagai hasil pengalaman unik seseorang dalam dirinya sendiri, dengan orang terdekat, dan dengan realitas dunia (Satrio. K, Damayanti. R \& Ardinata, 2015).

Penerimaan diri adalah sikap dalam menilai diri dan keadaannya secara objektif, menerima kelebihan dan kelemahannya. Menerima diri berarti telah menyadari, memahami dan menerima apa adanya dengan disertai keinginan dan kemampuan untuk selalu mengembangkan diri sehingga dapat menjalani hidup dengan baik dan penuh tanggung jawab (Paramita, 2012).

Berdasarkan hal tersebut peneliti berpendapat bahwa realistis bagi odapus akan meningkatkan kemampuannya menyesuaikan diri atas kondisi sakitnya, terutama dalam bentuk: kemampuan kontrol terhadap emosi yang berlebihan; memiliki respon positif dan langsung terhadap permasalahan; sikap yang realistik dan objektif; memiliki kemampuan belajar; mampu menjalin hubungan interpesonal; dan ketiadaan mekanisme pertahanan ego. Penerimaan diri juga dapat meningkatkan penilaian diri yang akan memberikan kontribusi pada dirinya sendiri mengenai tanggung jawab atas kondisi yang dialaminya serta tidak mencela apalagi menyalahkan orang lain. Individu yang menerima dirinya akan mengetahui potensinya dan mereka akan dapat memanfaatkan potensinya terlepas dari kelemahan yang dimilikinya karena mengalami Lupus.

\section{Kualitas hidup}

Berdasarkan hasil dari pengolahan data maka dapat diketahui bahwa kualitas hidup pada pasien lupus eritematosus sistemik (LES) di Komunitas Odapus Provinsi Lampung (KOL) Tahun 2018 sebagian besar dengan kategori tinggi sebanyak 25 responden $(62,5 \%)$, sedangkan dengan kategori rendah sebanyak 15 responden $(37,5 \%)$.

Teori yang dikemukakan Urifah (2012) bahwa kualitas hidup merupakan persepsi subjektif dari individu terhadap kondisi fisik, psikologis, sosial, dan lingkungan dalam kehidupan sehari-hari yang dialaminya. Kualitas hidup merupakan suatu terminology yang menunjukkan tentang kesehatanfisik, sosial dan emosi seseorang serta untuk melaksanakan tugas sehari-hari. Sedangkan teori Handini (2011) mengatakan bahwa kualitas hidup adalah tingkatan yang menggambarkan keunggulan seseorang individu yang dapat dinilai dari kehidupan mereka. Keunggulan individu tersebut biasanya dilihat dari tujuan hidupnya, kontrol pribadinya, hubungan interpersonal, perkembangan pribadi, intelektual dan kondisi materi.

Berdasarkan hal tersebut peneliti berpendapat bahwa tingginya kualitas hidup pada penderita Lupus tersebut dikarenakan masih tingginya hubungan interpersonal, perkembangan pribadi, intelektual dan kondisi materi pada pasien tersebut. Untuk itu disarakan bagi penderitas lupus untuk tetap mempertahankan kepercayaan diri melakukan kegiatan positif agar tidak memiliki anggapan aneh/abnormal terhadap diri sendiri serta tidak adanya rasa malu atau memperhatikan dirinya sendiri. 
3. Hubungan penerimaan diri dengan kualitas hidup

Hasil uji statistik $p$ value $=0,005$ lebih kecil dari nilai alpha $(\alpha=0,05)$, sehingga terdapat hubungan yang bermakna antara hubungan penerimaan diri dengan kualitas hidup pada pasien lupus eritematosus sistemik (LES) di Komunitas Odapus (KOL) Provinsi Lampung Tahun 2018. Hasil analisis diperoleh nilai OR: 11,556. Artinya penerimaan diri yang kurang baik memiliki risiko sebesar 11,556 kali kualitas hidup yang rendah dibandingkan dengan penerimaan diri yang baik.

Lupus eritematosus sistemik (LES) adalah suatu penyakit autoimun multisistem dengan manifestasi dan sifat yang sangat berubah-ubah. Secara klinis SLE merupakan penyakit kambuhan, dan sulit diperkirakan dari awal manifestasi yang akut atau tersamar yang sebenarnya dapat menyerang setiap organ tubuh, namun penyakit ini terutama menyerang kulit, ginjal, membran serosa, sendi dan jantung. Secara imunologis penyakit ini melibatkan susunan antibodi yang membingungkan yang secara klasik termasuk antibodi antinuklear (ANA) (Kumar, Cotran \& Robbins, 2012).

Penyakit LES merupakan penyakit inflamasi autoimun kronik, dengan etiologi yang belum diketahui. Manifestasi klinis, perjalanan penyakit dan prognosis penyakit LES sangat beragam. Sistem kekebalan tubuh pada penyakit ini akan mengalami kehilangan kemampuan untuk melihat perbedaan antara substansi asing dengan sel dan jaringan tubuh sendiri. Pada penyakit LES terjadi produksi antibodi yang berlebihan namun tidak menyerang kuman atau antigen tetapi menyerang sistim kekebalan sel dan jaringan tubuh sendiri. Antibodi seperti ini disebut "auto-antibodi" yang bereaksi dengan antigen "self" membentuk kompleks imun. Kompleks imun yang menempel dalam jaringan akan mengakibatkan terjadinya peradangan dan kerusakan pada jaringan (Kemenkes RI, 2016).
Hal ini sesuai dengan teori yang menyatakan bahwa Individu yang memiliki penyakit kronis dan tidak dapat disembuhkan seperti penyakit Lupus ini, seringkali merasa merasa dirinya diasingkan, merasa dirinya tidak berharga, merasa tidak dapat diterima oleh lingkungannya, merasa rendah diri, marah, kecewa, malu, emosi, lebih sensitif dan bersikap tertutup serta perasaan negatif lainnya. Berbagai macam tekanan, baik fisik maupun psikis seringkali mengakibatkan timbulnya penolakan pada diri si penderita, dimana penderita tidak dapat menerima kenyataan yang terjadi yang sedang dialaminya. Tidak jarang, individu yang menderita penyakit ini juga mengalami stres atau depresi. Individu yang memiliki penyakit seperti ini pun biasanya memiliki penerimaan diri yang kurang baik. Maka akibatnya penerimaan diri dengan keadaan penyakit Lupus pun menjadi persoalan (Nugroho, 2015).

Perempuan penderita Lupus akan mengalami perubahan pada dirinya, baik perubahan yang terjadi pada kemampuannya maupun penampilan secara fisiknya dan hal tersebut akan menimbulkan emosi yang negatif pada para penderita tersebut. Lebih lanjut ia menemukan bahwa proses penerimaan diri yang terjadi pada wanita penderita Lupus melalui tahapan penerimaan stress: 1) tahap penolakan, 2) kemarahan, 3) tawar-menawar, 4) depresi, dan 5). Factor yang mendukung penerimaan diri dipengaruhi oleh kemampuan resiliensi yang dimiliki masing-masing penderita, pemberian dukungan sosial yang sesuai dengan kebutuhan penderita, adanya harapan kesembuhan dan sejauh mana tercapainya harapan tersebut serta identifikasi yang dilakukan terhadap orang yang memiliki sikap positif. Dari data tersebut, dapat disimpulkan bahwa penerimaan diri penderita Lupus adalah suatu proses dinamika psikologis dalam pemikiran, perasaan dan perilaku. Dan dari proses inilah lahir peranan besar dalam melakukan pembentukan 
penyesuaian diri pada penderita Lupus (Utami, 2008).

Hasil penelitian ini memiliki kesamaan dengan penelitian yang dilakukan Paramita \& Margaretha (2013) tentang pengaruh penerimaan diri terhadap penyesuaian diri penderita lupus. Dari hasil analisis data penelitian diketahui bahwa ada korelasi positif antara penerimaan diri terhadap penyesuaian diri penderita lupus dengan nilai $r=0,760(p<0,001)$. Penelitian ini memberikan bukti empiris hubungan sebab-akibat antara penerimaan diri dan penyesuaian diri penderita Lupus; dimana semakin tinggi penerimaan diri, maka semakin tinggi pula penyesuaian dirinya.

$\begin{array}{lll} & \text { Kualitas hidup yang berhubungan } \\ \text { dengan kesehatan } & \text { merupakan }\end{array}$
keseluruhan kondisi status kesehatan seorang pasien, termasuk kesehatan fisik pasien, sosial, psikologis, dan ekonomi pasien. Penilaian kualitas hidup dipengaruhi oleh keadaan fisik, mental, sosial, dan emosional. Seorang penderita dengan lupus eritematosus sistemik (LES) dapat dinilai kualitas hidupnya berdasarkan salah satu faktor yaitu lama menderita lupus eritematosus sistemik (LES). Lama sakit berperan penting dalam kualitas hidup, ditemukan bahwa pasien dengan durasi lebih dari 10 bulan memiliki kualitas hidup yang buruk. Pasien ini memiliki trauma fisik dan emosional yang signifikan yang telah membatasi kegiatan sehari-hari mereka dengan kurang perhatian. Penderita juga mengalami khawatir, kelelahan, gangguan memori dan keputusasaan kesehatan. Mereka juga khawatir tentang efek samping jangka panjang dari obat dan memiliki dukungan sosial yang buruk (Shetty et al.,2011).

Berdasarkan hal tersebut menurut peneliti bahwa Individu yang memiliki penerimaan diri yang kurang baik biasanya disebabkan karena mereka tidak memiliki keyakinan akan kemampuannya untuk menghadapi persoalan dan merasa dirinya tidak berharga dan tidak berguna orang lain, dan akibatnya mereka juga akan kesulitan melakukan penyesuaian diri dengan kondisi sakitnya. Hal ini akan tampak pada kesulitan mereka untuk melakukan kepatuhan minum obat, melakukan kontrol pemeriksaan dan tes kesehatan dan dalam mengerjakan berbagai penyesuaian diri dan lingkungan pasca diagnosa Lupus.

\section{Kesimpulan}

1. Distribusi frekuensi penerimaan diri pada pasien lupus eritematosus sistemik (LES) di Komunitas Odapus Provinsi Lampung (KOL) Tahun 2018 sebagian besar dengan kategori kurang baik sebanyak 22 responden $(55,0 \%)$.

2. Distribusi frekuensi kualitas hidup pada pasien lupus eritematosus sistemik (LES) di Komunitas Odapus Provinsi Lampung (KOL) Tahun 2018 sebagian besar dengan kategori tinggi sebanyak 25 responden $(62,5 \%)$.

3. Ada hubungan antara penerimaan diri dengan kualitas hidup pada pasien lupus eritematosus sistemik (LES) di Komunitas Odapus (KOL) Provinsi Lampung Tahun 2018 ( $p$-value 0,005 < a 0,05). OR: 11,556 .

\section{DAFTAR PUSTAKA}

Angriyani, D. (2011). Kualitas Hidup pada Orang dengan Penyakit Lupus Erythematotus (Odapus). Skripsi Fakultas Psikologi Universitas Airlangga.

Azwar, S. (2015). Sikap manusia teori dan pengukurannya. Yogyakarta : Pustaka pelajar.

Dahlan, M.S. (2011). Statistik Untuk Kedokteran Dan Kesehatan. Salemba medika: Jakarta. 
Handini. (2011). Pengaruh Sense Of Humor Terhadap Kualitas Hidup Pada Lansia Pensiunan Di Kota Malang, Jurnal Psikologi, Malang: Universitas Brawijaya Malang.

Hurlock, E.B. (2008). Psikologis Perkembangan : Suatu Pendekatan Sepanjang RentangKehidupan. Jakarta : Erlangga.

Kemenkes RI. (2017). Situasi Lupus di Indonesia. Pusat data dan Informasi. Jakarta: Kemenkes Kesehatan RI.

Kemenkes RI. (2016). Pedoman Pengendalian Lupus Eritematosus Sistemik (LES). Pencegahan dan Pengendalian Penyakit Tidak Menular. Jakarta: Kemenkes Kesehatan RI.

Kumar. R. D.R. et al. (2012). Robbins. Buku Ajar Patologi. Volume 1. Edisi 7. Jakarta: EGC.

Nimas., Fitriana, A., Ambarani, T.K. (2012). Kualitas Hidup Pada Pasien Kanker Serviks yang Menjalani Pengobatan Radioterapi.Jurnal Psikologi Klinis dan Kesehatan Mental.Vol. 1. No. 02

Notoatmodjo, S. (2012). Metodologi Penelitian Kesehatan (Cetakan VI). Jakarta: Penerbit PT. Rineka Cipta.

Noviyanti. (2014). Penerimaan Diri Dan Daya Juang Pada Wanita Penderita
Systhemic Lupus Erythematosus (SLE). eJournal Psikologi, Volume 2, Nomor 2, 2014: 171 - 181.

Paramita \& Margaretha. (2013). Pengaruh penerimaan diri terhadap penyesuaian diri penderita lupus. Jurnal Psikologi Undip Vol.12 No.1 April 2013

Riyanto. A. (2011). Aplikasi Metodelogi Penelitian Kesehatan. Yogyakarta: Nuha Medika.

Saryono \& Anggraeni. (2013). Metode Penelitian Kualitatif dan Kuantitatif Dalam Bidang Kesehatan. Yogyakarta: Nuha medika.

Satrio, K., Damayanti., Ardinata, R. (2015). Buku Ajar Keperawatan jiwa. Pusat penelitian dan penerbitan LP2M Institut Agama Islam Negeri Raden Intan: Lampung.

Sudoyo dkk. (2014). Buku Ajar IImu Penyakit Dalam. Jilid III Edisi VI. Jakarta: Interna Publishing.

Suyanto. (2011). Metodelogi dan aplikasi penelitian keperawatan. Yogyakarta: Nuha Medika.

Urifah, R. (2012). Hubungan antara Strategi Koping dengan Kualitas Hidup Pada Pasien Skizofrenia Remisi Simptom.Jurnal Psikologi Klinis dan Kesehatan Mental.Vol. 1. No. 2 